\title{
e-Banking Adoption: An Opportunity for Customer Value Co-creation
}

\author{
Rocío Carranza1,2*, Estrella Díaz , Carlos Sánchez-Camacho² and \\ David Martín-Consuegra ${ }^{1}$
}

' Department of Marketing, University of Castilla-La Mancha, Ciudad Real, Spain, ${ }^{2}$ Faculty of Management and

Communication, Universidad Internacional de la Rioja, Logroño, Spain

The development of information and communication technologies offers innovative opportunities to establish business strategies focused on customer value co-creation. This situation is especially notable in the banking industry. e-Banking activities can support competitive advantages. However, the adoption of e-banking is not yet wellestablished among consumers. In this sense, the technology acceptance model (TAM) is considered essential in studying consumer behavior applied to adopt a particular technology. According to the TAM model, this study analyses the factors which influence bank customers to adopt e-banking to facilitate their banking services and support the process of value co-creation. Consequently, the authors examine five main aspects of

OPEN ACCESS

Edited by: Maria Angeles Garcia Haro, Open University of Catalonia, Spain

Reviewed by: Manuel Sanchez-Perez, University of Almería, Spain Fernando Fastoso, Pforzheim University of Applied Sciences, Germany

*Correspondence: Rocío Carranza rocio.carranza@uclm.es

Specialty section:

This article was submitted to Organizational Psychology, a section of the journal

Frontiers in Psychology

Received: 25 October 2020

Accepted: 21 December 2020

Published: 14 January 2021

Citation:

Carranza R, Díaz E

Sánchez-Camacho $C$ and

Martín-Consuegra D (2021)

e-Banking Adoption: An Opportunity

for Customer Value Co-creation.

Front. Psychol. 11:621248.

doi: 10.3389/fpsyg.2020.621248 the technology adoption model to provide a broad understanding of bank customers' consumption of e-banking. A partial least squares structural equation modeling (PLSSEM) analysis is conducted to evaluate proposed relationships between factors and customers' e-banking adoption.

Keywords: customer value co-creation, e-banking, e-services, technology acceptance model, PLS-SEM

\section{INTRODUCTION}

The rapid growth and development of information and communication technologies (ICT) have enabled companies to create value in a digital environment (Schreieck and Wiesche, 2017). Currently, the adoption of innovation in the organization's strategy is an essential requirement to create value. The term value co-creation has a principal role in easing this innovation. O'Hern and Rindfleisch (2010) conceptualize value co-creation as a collaborative activity, in which consumers actively participate and choose components of a different product or service proposition. Thus, in the digital era, value creation has become the co-creation of value between customers and companies (Hosseini et al., 2020).

Internet and technological development have changed how financial services are offered and used (Malaquias and Hwang, 2019). Banks and many financial institutions suggest alternative innovative electronic channels for maintaining a competitive advantage and satisfying customer expectations. Mobile devices and destock have increasingly become tools that customers implement through e-banking to pay for products and services (Zhang et al., 2018). Therefore, e-banking can adapt to clients' needs, such as performing banking activities, without physically visit an office or an ATM (Malaquias and Hwang, 2019). For this reason, e-banking has considerable value for many financial organizations and customers (Baabdullah et al., 2019).

The introduction and growth of Internet services, which offer better possibilities of interaction with companies, allow consumers to participate in the development and/or improvement of products/services, resulting in value. Consequently, organizations are concerned about attracting 
customers who want to contribute their ideas to the collaborative process (Chepurna and Criado, 2018). The banking context is particularly interesting in analyzing the transition toward a value co-creation strategy (Mostafa, 2020). The fierce competition in the banking arena has facilitated e-banking as the most cuttingedge electronic-based and self-service distribution channel (Malaquias and Hwang, 2019). e-Banking is conceptualized as a distribution and communication channel which allows customers to interact with a bank to conduct transactions economically and efficiently, mainly through electronic tools, e.g., tablets or smartphones (Singh and Srivastava, 2020). The use of e-banking offers a wide variety of services for customers, which provide them with value and create a competitive advantage over competitors, such as account checking, bill payment, transferences, or mobile phone text message notifications (Mostafa, 2020). As an example of this incremental service innovations, Bankia is modernizing their communication channels to increase the value offered to customers. Bankia has been recognized as the first Spanish bank with an official verified WhatsApp account to communicate with either current customers or prospects. This action is part of its business strategy "Digital Humanism" as a new way of relating to customers based on a closer, agile, and direct actions (Bankia, 2020).

The massive usage of the Internet and electronic gadgets have captured the attention of researchers to e-banking. Previous studies (e.g., Glavee-Geo et al., 2017; Singh and Srivastava, 2020) show that previous works have studied the factors that encourage the adoption of e-banking (Mostafa, 2020). However, the adoption rate of e-banking is below the expectation and still in the adoption phase, even though e-banking services offer several outstanding services to users (Shankar et al., 2020). Therefore, this study aims to develop an empirical model based on technology adoption, applied in e-banking to understand the behavior of the users. Specifically, some variables included in the technology acceptance model (TAM) will be examined as factors that stimulate the adoption of e-banking and become an opportunity for customer value co-creation.

For this reason, this research provides a series of contributions that can help identify decisive factors in the use of e-banking and encourage customer value co-creation through interaction with electronic services. In this setting, this study focuses on the following questions: What are the factors that affect a consumer's use of e-banking? What factors are most important in the consumer's intention to use e-banking? What type of e-banking is most in-demand, and what strategies around the use of e-banking could the banks and financial institutions follow to increase its use? How can the use of e-banking contribute to customer value co-creation? Through partial least squares structural equation modeling (PLS-SEM) approach and the use of the importanceperformance map analysis (IPMA), this research field provides insights and recommendations to help the banking industry adopt and use e-services by consumers to support the process of value co-creation.

To achieve the proposed objective, the study is organized as follows. First, the conceptual framework, the proposed model, and its hypotheses are presented. Then, the methods used and the results of the study are described. Finally, the conclusions and limitations of the study are presented.

\section{CONCEPTUAL FRAMEWORK}

\section{Co-creation and the Banking Market}

The banking industry is a leader in providing consumers with opportunities to access products and services through advanced technology (Malar et al., 2019). The development of ICT has allowed banks to have a relationship with customers, shifting away from physical interaction with a bank branch to interactive and virtual environments (Martovoy and Santos, 2012). Some authors, such as Andreu et al. (2010), specify the consequences of direct interactions between a company and its customers to achieve value co-creation. Other researchers, such as Payne et al. (2008), highlight that organizations must adopt a customer relationship approach to support value creation. Co-creation requires companies' ability to connect with customers and market orientation to be closer to them (Ind and Coates, 2013). Consequently, the company-client relationship must be active, providing interactive experiences and activities guided by decisive practices while taking advantage of customers' unconscious behavior. In this sense, customers are encouraged to participate in the process and meet their own needs.

Following the study of Grönroos (2011), consumers ought to perceive usefulness or benefit using self-service and involvement in the process to be motivated. In the banking sector, there is a generalized interest in providing easy and fast services, maintaining the quality of products, and services toward the customer. Furthermore, the advent of new technologies, products, and services encourages new needs and demands by customers (Hosseini et al., 2020). Ease access to information and the differentiation of products and services offered by the Internet creates higher expectations among customers. Consequently, an innovation that appears in a specific part of the work may be effortlessly accessed in other parts of the world and desired by any person (Mainardes et al., 2017). Another feature of electronic services is accessibility to consumers. Some studies indicate that banking services are linked to this new and demanding customer profile. Consequently, the new services provided by banks arise from customers' needs, characterizing the continuous sharing of ideas and value co-creation in the banking sector (Oliveira and von Hippel, 2011; Akter et al., 2020).

Based on the study of Medberg and Heinonen (2014), direct contact with the company and e-services create new ways of relationship and involvement with customers, positively affecting the company's financial performance (e.g., decreasing of operating costs, increase on investment return). Furthermore, this way of interacting with customers has boost competitiveness in the banking industry, requiring an agile adaptation from each financial organization. It is proven that, when a bank includes a new or enhanced service to customers, competitors follow this innovation through the launch of the same or improved service. Thus, co-creation characterizes the innovation and betterment of services provided by banks. This fact encourages customers' active participation in the co-creation practice through several 
benefits: easer credit approval, lower charges, or commitment to the bank (Mostafa, 2020). Hence, value co-creation should drive to reciprocally favorable outcomes for both consumers and businesses.

\section{Adoption of Technology and e-Services Banking}

In recent years, the development of Information Technology and the Internet has brought about changes in the performance of traditional services. Thus, e-banking has changed the conventional practices of banks and financial institutions and has captured the attention of both academics and practitioners (Wang et al., 2017). The adoption of e-banking is considered an innovative distribution channel for financial services due to rapid advances in e-banking applications and intense competence (Sikdar et al., 2015; Yaseen and El Qirem, 2018). Thus, understanding the adoption and use of e-banking has become a central research field. The literature indicates that the most relevant strength of the TAM, developed by Davis et al. (1989), is its generalizability and applicability in different contexts (Yaseen and El Qirem, 2018). This model is specifically indicated to study the intention to adopt specific technologies. Thus, the TAM applies models to study the acceptance and intention to use information system tools such as mobile commerce (e.g., Natarajan et al., 2018), m-banking (e.g., Mostafa, 2020; Shankar et al., 2020) and e-banking (Yoon and Steege, 2013; Salimon et al., 2017; Yaseen and El Qirem, 2018; Ahmad et al., 2019), among others. The original TAM considers perceived usefulness and perceived ease of use has a significant role in the technology acceptance process (Davis et al., 1989). On one side, perceived ease of use is defined as the degree to which a person believes that using a particular system is effortless, both physically and mentally. On the other side, perceived utility is described as the degree to which consumers believe that using a system will increase their performance (Davis et al., 1989; Mostafa, 2020). Some previous studies in technology acceptance demonstrate that perceived ease of use has a positive effect, mediated by perceived usefulness on the intention to use technology (Natarajan et al., 2018).

In the context of e-banking, it is observed that perceived usefulness represents one of the critical aspects that explain behavior intention to use e-banking (Malaquias and Hwang, 2019). For example, e-banking provides some unique services that are not available in offline banking, such as access to banking services at any time and from anywhere (Yoon and Steege, 2013; Shankar and Jebarajakirthy, 2019). Similarly, previous studies show the influence of perceived ease of using e-banking on perceived usefulness and attitude (e.g., Deb and LomoDavid, 2014). Internet and mobile technology should improve convenience for customers, and its ease of use is critical in customer usage. Some authors (e.g., Riquelme and Rios, 2010) claim that adopting mobile banking is influenced by consumer's perceived ease of use due to a complex system when it performs financial transactions. In this sense, the authors highlight that if consumers perceive the performance of a financial transaction as easy through mobile devices, they will have a more favorable attitude toward adopting mobile banking (Zhang et al., 2018). Ahmad et al. (2019) argue that a client's beliefs about the usability of the website or application affect his or her attitude toward the website or application. These authors state that the ease of use of e-banking systems is a critical factor in their adoption and evaluation by clients. Thus, the relationship between consumers' attitudes toward the use of technology, an excellent example of this is e-banking, and perceived ease of use is studied (e.g., Zhang et al., 2018). Moreover, Mostafa (2020) argues that customers may negatively evaluate using e-banking if they believe e-banking technology is challenging to use and learn. Thus, the following hypotheses are proposed:

H1. Perceived ease of use positively influences on perceived usefulness of e-banking.

H2. Perceived ease of use positively influences on attitude toward using e-banking.

Another dimension included in the TAM model is the perceived usefulness. This concept and its role have been examined in e-banking works (e.g., Yoon and Steege, 2013; Salimon et al., 2017; Malaquias and Hwang, 2019). Perceived usefulness can be defined as a person's belief about if the use of a specific technology will improve their task performance (Davis et al., 1989; Natarajan et al., 2018). Authors such as Yoon and Steege (2013) state that perceived utility is a positive and determining element in e-banking usage. Similarly, this term is the principal factor that impacts consumers' attitudes toward the use of technology (Deb and Lomo-David, 2014). Consequently, customers will evaluate e-banking usage favorably if they perceive that e-banking has a relative advantage over other alternatives (Mostafa, 2020). Recently, authors such as Ahmad et al. (2019) have highlighted the positive relationship of perceived usefulness with both attitudes toward using e-banking and user intention. According to the previous statements, the following hypotheses are formulated:

H3. Perceived usefulness positively influences on attitude toward using e-banking.

H4. Perceived usefulness positively influences on intention to use e-banking.

The concept of attitude toward the behavior reflects the degree to which an individual assesses a specific behavior as useful or not (Ajzen, 1991). Venkatesh et al. (2003) interpret attitudes toward a specific innovation as results of an individual's own beliefs about an objective and the evaluations associated with those beliefs. In TAM's scope, positive attitudes toward innovative technologies have confirmed antecedents of intentions to adopt them (Davis et al., 1989; Schierz et al., 2010). The association among attitude and intention to use has been broadly examined in the literature, particularly in the banking literature (e.g., Shaikh and Karjaluoto, 2015; Zhang et al., 2018; Ahmad et al., 2019; Mostafa, 2020).

Similarly, past research shows that attitude is an essential determinant of behavioral intention and a relevant antecedent of actual behavior. Consequently, the intention to adopt has been analyzed to understand people's actual behavior (Davis 


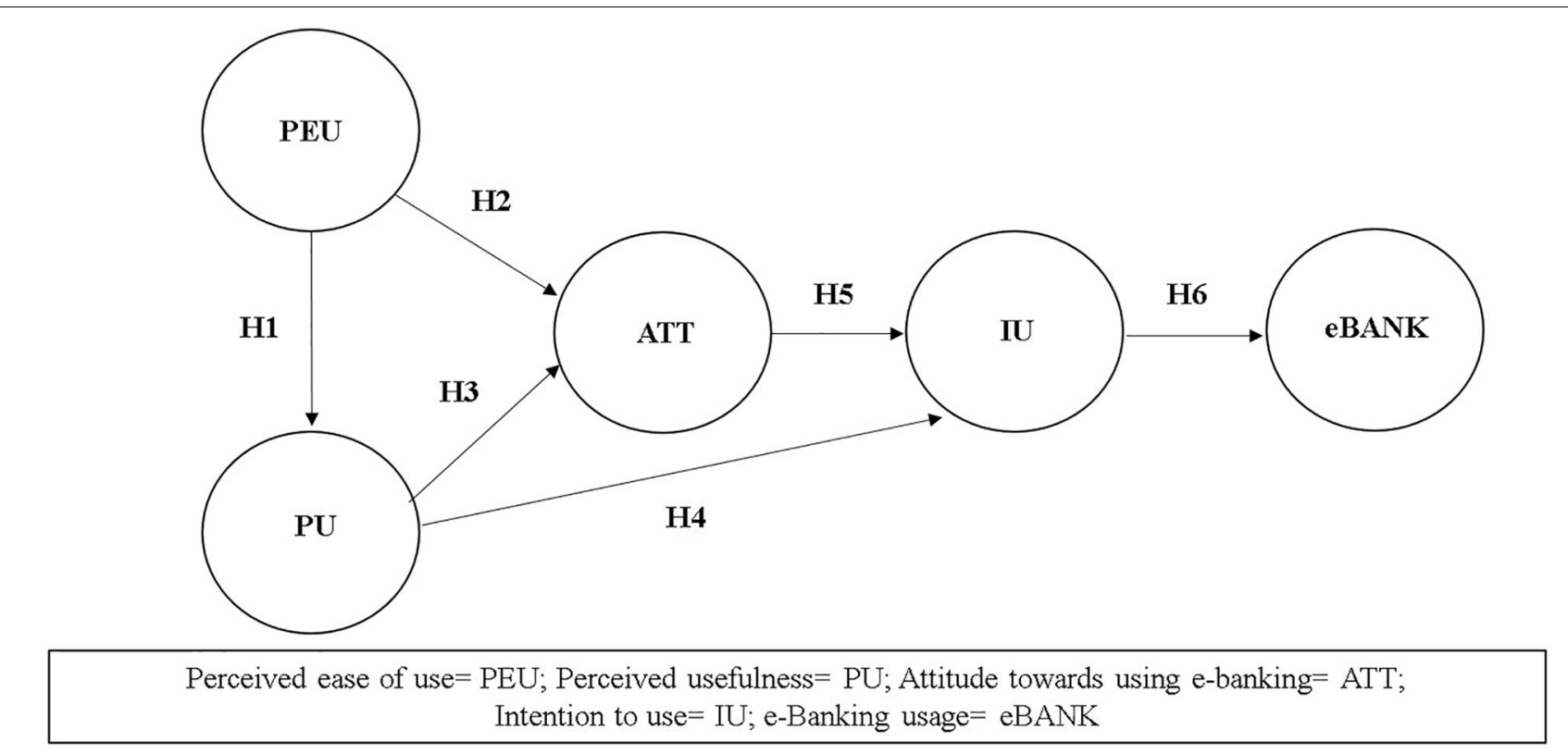

FIGURE 1 | Model proposed on the e-banking usage with PLS-SEM.

et al., 1989; Zhang et al., 2018). Yaseen and El Qirem (2018) conceptualize behavior intention to adopt e-banking services as a measure of the strength of an individual's intention to perform a specific behavior. Also, authors such as Ahmad et al. (2019) explain behavioral intention to use e-banking as a precedent to the actual use of e-banking. Based on prior studies, the following hypotheses are proposed:

H5. Attitude toward using e-banking positively influences on intention to use e-banking.

H6. Intention to use e-banking positively influences on e-banking usage.

Based on the above, Figure 1 summarizes the hypotheses of the proposed conceptual model.

\section{MATERIALS AND METHODS}

\section{Study Design}

To test the proposed hypotheses, the authors carried out a study in Southern Europe's banking industry. Specifically, the research was conducted in Spain due to the recent increase in e-banking in this country. e-Banking has experienced a growing acceptance in Spain in recent years, with more than $50 \%$ of digital banking population users. Some figures indicate that the number of Spain's e-banking users increased to 28\% between 2011 and 2019 (Statista, 2020a). Santander Group ranked first with more than 36 million digital customers during 2019, followed by BBVA with 31 million (Statista, 2020b).

A convenience sampling method was used to collect the data, taking e-banking users' opinions as reference. A convenience sampling method was used to collect the data, taking e-banking users' opinions as reference. Data was collected via an online survey from February to April 2020. Potential respondents in Spain were recruited through a national consumer panel. To measure each of the constructs, a self-administered survey has been used to analyze the e-banking usage of a set of wellknown banks located in Spain. The application of PLS-SEM requires a minimum sample size. For this purpose, the statistical power is analyzed using $\mathrm{G}^{*}$ Power 3.1.9.7 (Carranza et al., 2020). Thus, the statistical power value for this sample considering a medium effect size $\left(f^{2}=0.15\right)$ is 0.989 , higher than the established minimum of 0.8 (Cohen, 1988; Hair et al., 2019). Of 105 e-banking users (see Table 1), 45.7\% of the sample collected is composed of men and $54.3 \%$ of women. Concerning age, the largest group is integrated by individuals between 24 and 33 years old, representing $32.4 \%$ of the sample. In addition, the accumulated percentage of consumers up to 43 years of age is $67.6 \%$. Hence, the sample is predominantly made up of young adults and mid-aged e-banking users. Thus, this study coincides with previous studies in e-banking such as Zhang et al. (2018), Malaquias and Hwang (2019), Mostafa (2020), Singh and Srivastava (2020), where the samples are mostly composed of young people considered more likely to use digital technologies and media. Moreover, $35.3 \%$ of the respondents are employees, $43.8 \%$ are singles, and $37.1 \%$ are married. Concerning consumption factors, $93.3 \%$ of the sample uses e-banking to check their bank account balance, 49.5\% make bank transfers through e-baking, and $15.2 \%$ manage invoices and taxes.

\section{Measures}

In order to measure the constructs included in this study and examine the proposed relationships, a structured questionnaire was used. Firstly, questions related to the frequency and habits 
TABLE 1 | Characteristics of the survey sample.

\begin{tabular}{|c|c|c|}
\hline Customer profile & Categories & Sample (percentage) \\
\hline \multirow[t]{2}{*}{ Gender } & Men & 45.7 \\
\hline & Woman & 54.3 \\
\hline \multirow[t]{6}{*}{ Age } & $\geq 23$ & 17.1 \\
\hline & $24-33$ & 32.4 \\
\hline & $34-43$ & 18.1 \\
\hline & $44-53$ & 14.3 \\
\hline & $54-63$ & 9.5 \\
\hline & +64 & 8.6 \\
\hline \multirow[t]{6}{*}{ Occupation } & Student & 21.9 \\
\hline & Employed person & 35.3 \\
\hline & Self-employed person & 19.0 \\
\hline & Retired person & 10.5 \\
\hline & Unemployed & 11.4 \\
\hline & Other & 1.9 \\
\hline \multirow[t]{5}{*}{ Civil status } & Single & 43.8 \\
\hline & Married & 37.1 \\
\hline & Living as a couple & 10.5 \\
\hline & Separated or divorced & 5.7 \\
\hline & Other & 2.9 \\
\hline
\end{tabular}

of the use of electronic banking were included. Then, the variables associated with the attitude and behavior toward using e-banking were exposed. All these constructs were evaluated with multi-item scales confirmed by previous studies, using a Likert scale ranging from 1 to 5 , except the construct intended to use, presented on a semantic differential scale (see Table 2). Thus, variables for perceived ease of use were based on Davis et al. (1989) and Venkatesh et al. (2003). The attitude toward using e-banking was measured through a semantic differential scale using six items (five bipolar pairs of adjectives). Several authors, such as Stern and Salb (2015), define the attitude as a formative construct characterized mainly by affective aspects and instrumental distinctions. According to the scales proposed by Davis et al. (1989), Venkatesh et al. (2003), and Carranza et al. (2020) in the area of technology acceptance, the attitude variable was measured using three significant items (unpleasantattractive, unsatisfactory-satisfactory, boring-fun) and three instrumental items (bad-good, uninteresting-appealing, harmfulbeneficial).

The perceived usefulness was measured using the Agarwal and Karahanna (2000) scale, following Mostafa's (2020) work. Intention to use was measured using a single-item scale based on previous research, such as Bigné et al. (2008). Three items adapted from Davis et al. (1989) and Dutot (2015) were used to measure e-banking usage. The last section of the questionnaire aims to collect information on the socio-demographic profile of e-banking users, such as gender, age, or occupation.

\section{Statistical Analysis}

The model was estimated using PLS-SEM. PLS-SEM is a technique of structural equation models based on variance. In this study, the use of PLS-SEM is recommended because (1) the study
TABLE 2 | Measurement of key concepts.

\begin{tabular}{|c|c|c|}
\hline Construct & Adapted items & Scale origin \\
\hline \multirow[t]{6}{*}{$\begin{array}{l}\text { Perceived ease } \\
\text { of use (PEU) }\end{array}$} & PEU1: I find using e-banking easy. & $\begin{array}{l}\text { Adaptation of Davis } \\
\text { et al. (1989); } \\
\text { Venkatesh et al. } \\
\text { (2003) }\end{array}$ \\
\hline & $\begin{array}{l}\text { PEU2: I use e-banking without any } \\
\text { help. }\end{array}$ & \\
\hline & $\begin{array}{l}\text { PEU3: I use e-banking without any } \\
\text { problem. }\end{array}$ & \\
\hline & $\begin{array}{l}\text { PEU4: I consider myself an expert in } \\
\text { the use of e-banking. }\end{array}$ & \\
\hline & $\begin{array}{l}\text { PEU5: Using e-banking does not } \\
\text { require a tremendous mental effort. }\end{array}$ & \\
\hline & $\begin{array}{l}\text { PEU6: In general, I think it is easy to } \\
\text { use e-banking. }\end{array}$ & \\
\hline \multirow[t]{5}{*}{$\begin{array}{l}\text { Perceived } \\
\text { usefulness (PU) }\end{array}$} & $\begin{array}{l}\text { PU1: Using e-banking enhances my } \\
\text { effectiveness in living and working. }\end{array}$ & $\begin{array}{l}\text { Adaptation of } \\
\text { Agarwal and } \\
\text { Karahanna (2000); } \\
\text { Mostafa (2020) }\end{array}$ \\
\hline & $\begin{array}{l}\text { PU2: Using e-banking enhances my } \\
\text { productivity. }\end{array}$ & \\
\hline & $\begin{array}{l}\text { PU3: I find e-banking useful in my living } \\
\text { and working activities. }\end{array}$ & \\
\hline & $\begin{array}{l}\text { PU4: Using e-banking improves my } \\
\text { performance in living and working. }\end{array}$ & \\
\hline & $\begin{array}{l}\text { PU5: In general, using e-banking is very } \\
\text { useful. }\end{array}$ & \\
\hline \multirow[t]{6}{*}{$\begin{array}{l}\text { Attitude toward } \\
\text { using } \\
\text { e-banking (ATT) }\end{array}$} & ATT1: Bad - good & $\begin{array}{l}\text { Adaptation of Davis } \\
\text { et al. (1989); } \\
\text { Venkatesh et al. } \\
\text { (2003) }\end{array}$ \\
\hline & ATT2: Uninteresting - appealing & \\
\hline & АTT3: Harmful - beneficial & \\
\hline & ATT4: Unpleasant - attractive & \\
\hline & ATT5: Unsatisfactory - satisfactory & \\
\hline & ATT6: Boring - fun & \\
\hline $\begin{array}{l}\text { Intention to use } \\
\text { (IU) }\end{array}$ & $\begin{array}{l}\text { IU1: Will you use e-banking in the next } \\
3 \text { months? } 1 . \text { No, definitely not } 2 \text {. } \\
\text { Probably not } 3 \text {. Indifferent } 4 \text {. Yes, } \\
\text { probably } 5 \text {. Yes definitely }\end{array}$ & $\begin{array}{l}\text { Adaptation of Bigné } \\
\text { et al. (2008) }\end{array}$ \\
\hline \multirow[t]{3}{*}{$\begin{array}{l}\text { e-Banking } \\
\text { usage (eBANK) }\end{array}$} & $\begin{array}{l}\text { eBANK1: I have no problem with the } \\
\text { use of e-banking. }\end{array}$ & $\begin{array}{l}\text { Adaptation of Davis } \\
\text { et al. (1989); Dutot } \\
(2015)\end{array}$ \\
\hline & $\begin{array}{l}\text { eBANK2: No one influences my } \\
\text { decision to use e-banking. }\end{array}$ & \\
\hline & $\begin{array}{l}\text { eBANK3: I have enough experience } \\
\text { with new technologies to use } \\
\text { e-banking. }\end{array}$ & \\
\hline
\end{tabular}

includes a formative construct (attitude toward using e-banking), (2) the model uses composite models (Hair et al., 2019), and (3) PLS-SEM is applied in recent studies of TAM, in the field of e-banking, as well as in other different areas (e.g., Salimon et al., 2017; Carranza et al., 2020; Zollo et al., 2020). To estimate the proposed model, SmartPLS 3.2.9 was used. According to Hair et al. (2019), a two-stage approach is used to evaluate the proposed model in this e-banking customers' context. Thus, the measurement model is evaluated distinguishing the variables 
considered as a composite model in Mode A and Mode B, and then, the structural model is assessed.

\section{RESULTS}

\section{Measurement Model}

First, the standardized root mean square residual (SRMR) of the proposed model is calculated in order to assess the model fit (Henseler et al., 2016). In this case, the SRMR value is 0.070 , indicate an appropriate fit, given the accepted 0.008 cutoff point. To evaluate the measurement model, the reliability of the scales is studied for the construct's perceived ease of use, perceived usefulness, intention to use, and e-banking usage (Mode A). Thus, the loadings of the indicators are examined, all of which are higher than 0.708 . The evaluation of individual reliability is examined through the Dijkstra-Henseler's rho $\left(\rho_{A}\right)$ and the composite reliability (CR) being higher than 0.7 in all cases (Hair et al., 2019). Therefore, all the variables included in the model reflect high internal consistency (see Table 3). Then, the average variance extracted (AVE) is used to evaluate convergent validity. In this case, all values of the AVE are within the established thresholds limits (Fornell and Larcker, 1981). Lastly, all loadings are significant at 99.9\% (Hair et al., 2017). Concerning the analysis of the discriminant validity, the results obtained by the Fornell-Larcker criterion show a satisfactory degree of discriminant validity. However, Henseler et al. (2015) suggest construct thresholds below 0.9 for HTMT to establish discriminant validity. In this case, problems of discriminant validity between PEU and PU are detected. For that reason, the items causing the problem are studied and eliminated (see Table 4).

To evaluate the validity of the attitude toward using e-banking, the variance inflation factor (VIF) is used to assess the lack of

TABLE 3 | Measurement model evaluation.

\begin{tabular}{|c|c|c|c|c|}
\hline $\begin{array}{l}\text { Construct/associated } \\
\text { items }\end{array}$ & Loading & $\begin{array}{c}\text { Dijkstra-Henseler's } \\
\text { rho }\left(\rho_{A}\right)\end{array}$ & CR & AVE \\
\hline \multicolumn{5}{|l|}{ PEU (Mode A) } \\
\hline PEU2 & $0.924^{\star \star \star}$ & 0.906 & 0.937 & 0.831 \\
\hline PEU4 & $0.912^{\star \star \star}$ & & & \\
\hline PEU5 & $0.899^{\star \star \star}$ & & & \\
\hline \multicolumn{5}{|l|}{ PU (Mode A) } \\
\hline PU1 & $0.916^{\star \star \star}$ & 0.900 & 0.936 & 0.831 \\
\hline PU3 & $0.923^{\star \star \star}$ & & & \\
\hline PU4 & $0.895^{\star \star \star}$ & & & \\
\hline \multicolumn{5}{|l|}{ IU (Mode A) } \\
\hline IU1 & $1.000^{\star \star \star}$ & 1.000 & 1.000 & 1.000 \\
\hline \multicolumn{5}{|l|}{ eBANK (Mode A) } \\
\hline eBANK1 & $0.918^{\star \star \star}$ & 0.934 & 0.926 & 0.807 \\
\hline eBANK2 & $0.852^{\star \star \star}$ & & & \\
\hline eBANK3 & $0.923^{\star \star \star}$ & & & \\
\hline
\end{tabular}

$n=5,000$ subsample: ${ }^{* *} p<0.001$ (one-tailed $t$ Student). CR, composite reliability; $A V E$, average variance extracted; $P E U$, perceived ease of use; $P U$, perceived usefulness; IU, intention to use; eBANK, e-banking usage. collinearity problems by the indicators (VIF < 5) (see Table 5). Finally, for the significance value of the weights, ATT4 and ATT6 are not significant. However, according to Hair et al. (2019), since there are no collinearity problems and the loads are greater than 0.5 , these indicators are not deleted.

\section{Structural Model}

After checking the reliability and validity of the measurement model, the proposed structural model is examined. To do this, the explanatory capacity of the model is evaluated using $R^{2}$ (Hair et al., 2019). The $R^{2}$ values are 0.657 for perceived usefulness, 0.530 for attitude toward using e-banking, 0.462 for intention to use, and 0.324 for e-banking usage. After performing an analysis of the variance decomposition, the findings confirm that, of the $53 \%$ of the explained variance of attitude toward using e-banking, $29.1 \%$ is due to perceived ease of use and $23.9 \%$ to perceived usefulness. Similarly, of the $46.2 \%$ of explained variance of intention to use, $14.4 \%$ is due to perceived usefulness, and $31.8 \%$ is due to attitude toward using e-banking. Even though these results confirm significant relationships, the influence of consumers' attitudes toward the intention to use e-banking is greater than the contribution of the perceived usefulness.

On the other hand, the path coefficients and their significance are evaluated to describe the significance of the structural relationships proposed in the model (see Table 6). Perceived ease of use appears to be positive and significant, at $99.9 \%$ in perceived usefulness. Thus, $\mathrm{H} 1$ is supported, being the most solid association of the model $(\beta=0.811)$. As proposed in $\mathrm{H} 2$ and $\mathrm{H} 3$, perceived ease of use and perceived usefulness are positively associated with the attitude toward using e-banking $(\beta=0.417$ and 0.348 , respectively). Similarly, perceived usefulness has a significant influence on the intention to use of e-banking, also confirming $\mathrm{H} 4$ ( $\beta=0.248$ ). Also, attitude toward using e-banking, in general, has a significant and positive effect on the intention to use e-banking. Thus, $\mathrm{H} 5$ is established ( $\beta=0.485)$. Finally, the intention to use has a significant influence on e-banking usage. Therefore, H6 is also confirmed ( $\beta=0.569$ ) (Hair et al., 2019). Thus, hypotheses $\mathrm{H} 1, \mathrm{H} 2, \mathrm{H} 3, \mathrm{H} 4, \mathrm{H} 5$, and $\mathrm{H} 6$ are accepted by the percentile method.

After evaluating and confirming the proposed model, the effect size is evaluated (Hair et al., 2019). Thus, the results show

TABLE 4 | Measurement model: discriminant validity.

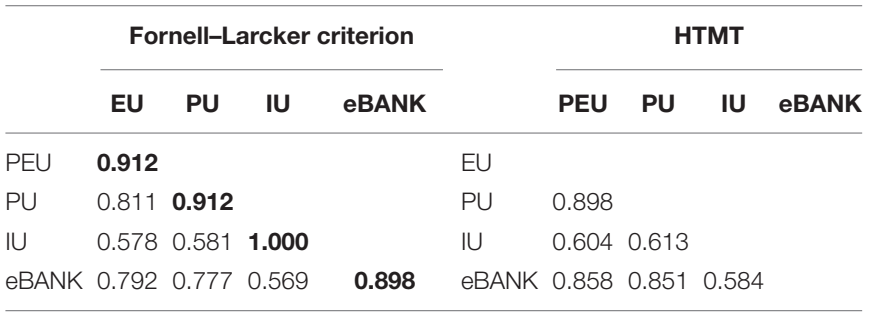

$P E U$, perceived ease of use; $P U$, perceived usefulness; IU, intention to use; eBANK, e-banking usage; AVE, average variance extracted. Fornell-Larcker criterion: diagonal elements (bold) are the square root of the variance shared between the constructs and their measures (average variance extracted). Off-diagonal elements should be larger than off-diagonal elements. 
TABLE 5 | Measurement model: model composite Mode B.

\begin{tabular}{|c|c|c|c|c|c|c|c|}
\hline \multirow[b]{2}{*}{ Constructs } & \multirow[b]{2}{*}{ Loading } & \multirow[b]{2}{*}{ Weights } & \multirow[b]{2}{*}{$t$} & \multirow[b]{2}{*}{ Sig } & \multicolumn{2}{|c|}{ Weights bootstrapping } & \multirow{2}{*}{$\begin{array}{c}\text { Collinearity statistic } \\
\text { VIF }\end{array}$} \\
\hline & & & & & $5 \%$ & $95 \%$ & \\
\hline \multicolumn{8}{|c|}{ Attitude toward using e-banking (Mode B) } \\
\hline ATT1 & 0.879 & $0.524^{\star \star}$ & 2.787 & 0.003 & 0.175 & 0.794 & 2.040 \\
\hline ATT2 & 0.864 & $0.317^{\star}$ & 1.814 & 0.035 & 0.003 & 0.583 & 3.535 \\
\hline АТT3 & 0.541 & $0.237^{*}$ & 1.844 & 0.033 & -0.455 & -0.035 & 1.927 \\
\hline ATT4 & 0.795 & $0.065^{(n s)}$ & 0.414 & 0.339 & 0.166 & 0.352 & 3.154 \\
\hline ATT5 & 0.856 & $0.298^{*}$ & 1.839 & 0.033 & 0.010 & 0.548 & 4.002 \\
\hline АTT6 & 0.764 & $0.113^{(n s)}$ & 0.816 & 0.207 & 0.117 & 0.345 & 2.719 \\
\hline
\end{tabular}

$n=5,000$ subsample: ${ }^{* *} p<0.01 ;{ }^{*} p<0.05 ; n s$, non-significant (one-tailed $t$ Student).

TABLE 6 | Structural model evaluation.

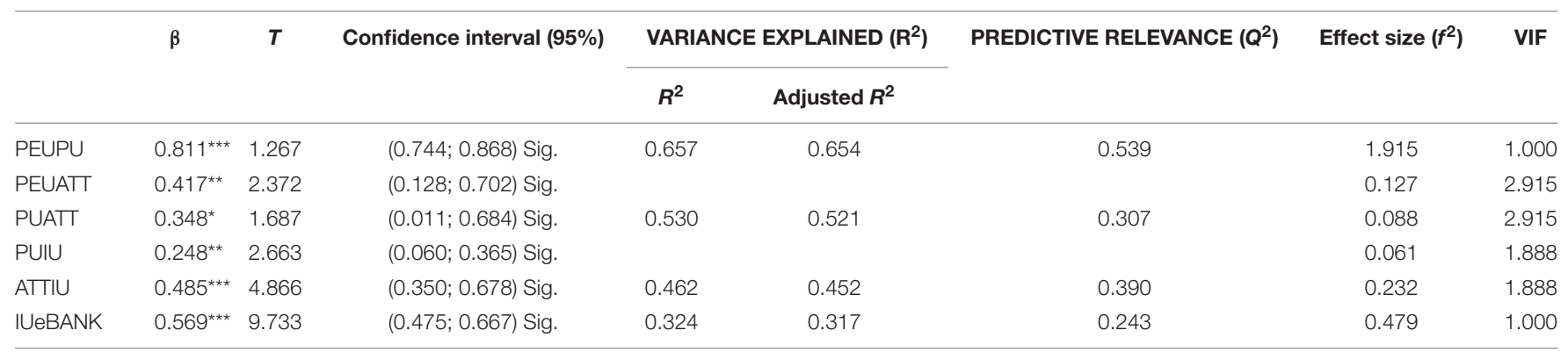

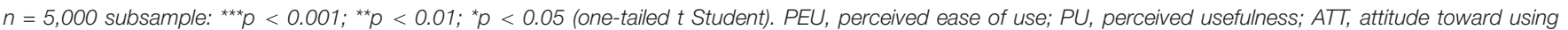
e-banking; $U$, intention to use; eBANK, e-banking usage.

that (see Table 6), the perceived ease of use has a large effect size on perceived usefulness $\left(f^{2}=1.915\right)$. Likewise, the intention to use has a significant and large effect size on e-banking usage $\left(f^{2}=0.479\right)$. Finally, the model's predictive relevance is analyzed. In this case, Stone-Geisser's $Q^{2}$ shows that the scores are higher than naught (see Table 6).

To improve these results, the IPMA is used. The IPMA expands the reported PLS-SEM results for path coefficient estimates by adding a dimension to the analysis that considers the mean values of the latent variable scores (Ringle and Sarstedt, 2016). In this case, the IPMA for e-banking users (see Figure 2) shows that intention to use is observed to be the most critical factor in determining e-banking usage. An increase of one point in the performance of intention to use by a total effect of 0.786. Attitude toward using e-banking has higher importance on e-banking usage but lower than the intention to use. Similarly, the attitude has a lower performance than the intention to use. The perceived ease of use is the factor with the lowest performance. Finally, perceived usefulness has the lowest importance in determining e-banking usage (see Figure 2).

\section{DISCUSSION}

This study developed a research framework to understand the factors that contribute to e-banking usage and to benefit business strategies based on the co-creation of consumer value. The model provides a comprehensive view of the main factors influencing e-banking intentions and the elements that should be considered to increase usage.

The results obtained concerning the application of TAM in the context of e-banking confirm the presence of significant relationships among perceived ease of use and perceived usefulness by the customer, being the most real relationship of the proposed model. Similarly, the relationships between perceived usefulness and attitude toward using e-banking, perceived ease of use and attitude toward using e-banking are also contrasted. However, the importance that perceived ease of use acquires in the attitude toward using e-banking is slightly higher than the influence that perceived usefulness has on this variable. Similarly, the relationships between perceived usefulness and intention to use, and attitude toward using e-banking and intention to use are also contrasted with previous studies, such as Salimon et al. (2017), Zhang et al. (2018), and Malaquias and Hwang (2019). Nevertheless, the results of the analysis of variance decomposition indicate that attitude toward using e-banking has relatively greater importance in intention to use compared to perceived usefulness. Therefore, an essential contribution of this research is the determination of attitude as a critical element in the determination of e-banking use intention. These results suggest that when e-banking users have a positive attitude toward using e-banking, it translates into a greater intention to use e-banking. Finally, the relationship between intention to use and e-banking usage is also verified, being the second strongest relationship of the model. In this sense, the results obtained by the IPMA analysis indicate that the intention to use is the variable 


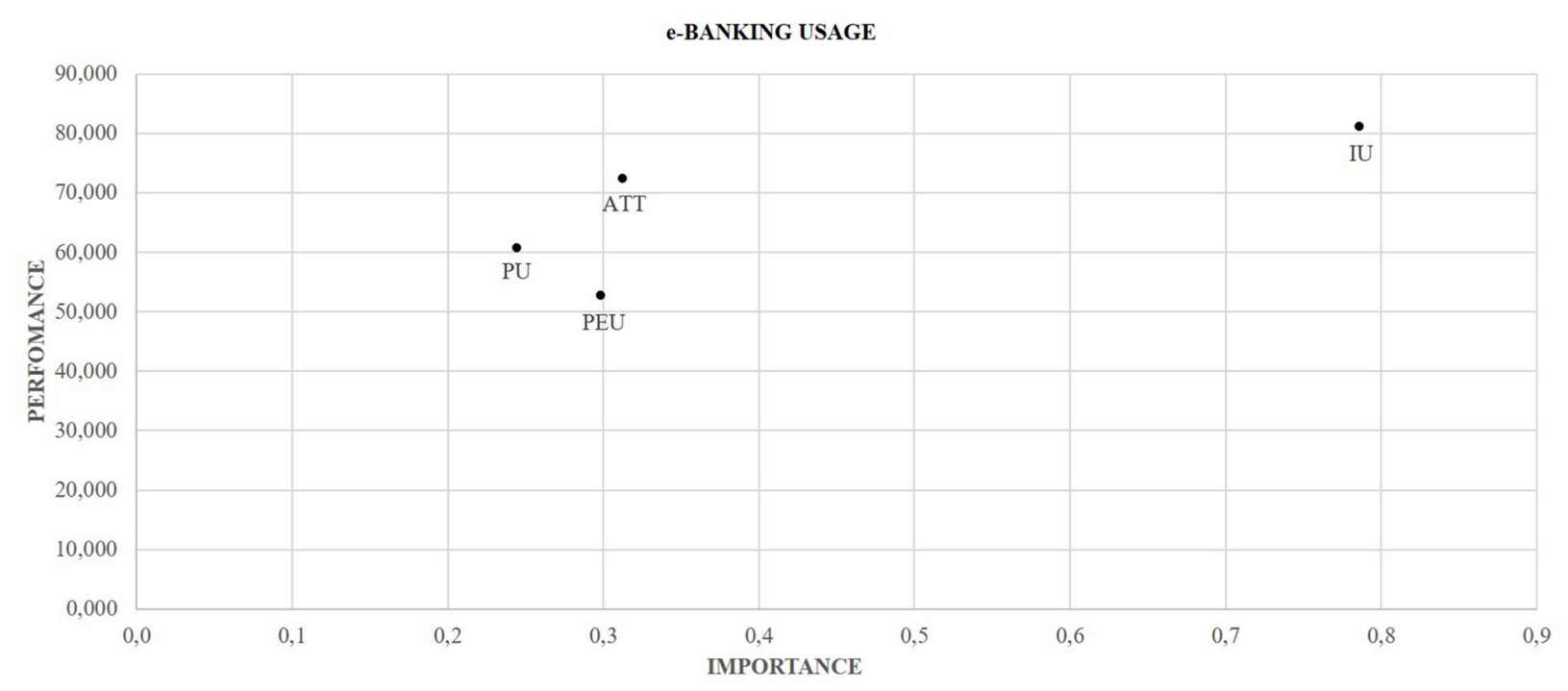

Perceived ease of use $=$ PEU; Perceived usefulness $=$ PU; Attitude towards using e-banking $=$ ATT; Intention to use $=$ IU

FIGURE 2 | Importance-performance map analysis (IPMA) for e-banking usage.

with the highest performance and the greatest importance in determining the adoption of e-banking. However, the perception of ease of use, despite the great importance in determining the use of e-banking, is the variable with the lowest performance in the proposed model.

These findings offer important implications for banks and financial institutions. The techniques and results of this study allow banks to identify possible deficiencies and apply improvements to establish greater interaction with their clients. Also, this study offers bank managers new tools that encourage co-creation through e-banking services, helping to achieve a competitive advantage.

Based on the results obtained, bank managers should pay special attention to the perceived ease of use and perceived usefulness of their e-services, since they contribute significantly to the adoption of e-banking by consumers. Perceived ease of use of e-banking services is one of the most relevant factors in the adoption of e-banking by consumers. However, the IPMA indicates that it is the factor with the lowest performance. As a consequence, banks can improve the usability and simplicity of their e-services and the performance of a banking transaction to facilitate and increase the e-banking usage. Likewise, customer service can be provided to guide and help the efficient use of these applications. Specifically, some authors such as Mostafa (2020) recommend the use of chatbot to facilitate the use of e-banking and co-create. Concurrently, the findings have shown the great importance of attitude in generating intention to use e-banking by consumers. Therefore, banks should encourage this attitude in consumers through the ease of use and usefulness provided by e-services.

By and large, as technology and smartphone advance, consumers will continue to seek out more personalized and utilitarian services for their banking operations. Therefore, e-banking should be secure, and easy to learn and use. For this reason, providing reliable, userfriendly, and useful e-services are a crucial element in the interactions between consumer adoption of e-banking.

\section{Limitations and Further Research}

This study has some limitations that need to be addressed. The first limitation is the geographical location of the sample and the size of the sample. Future studies should incorporate a more significant number of online banking users covering a wider geographical area. Similarly, this study can increase the number of respondents between 34 and 53-year-old. Secondly, this study has not considered the moderating role of gender and age as socio-demographic variables. Previous authors, such as Natarajan et al. (2018), consider age as a great relevance in studies of acceptance of mobile applications. Further research may assess the moderating role of this variable in the proposed model. Thirdly, this model is based exclusively on functional characteristics of technology adoption, such as perceived ease of use and perceived usefulness. In the area of e-banking, authors such as Zhang et al. (2018) highlight other types of more emotional factors for the study of the adoption of e-banking services such as enjoyment or trust. Likewise, Singh and Srivastava (2020) highlight the perceived security in the factors of adoption of e-banking. Thus, a future proposal could include a combination of functional and emotional elements in e-banking environments. Finally, further research could incorporate external variables associated with value co-creation, such as the confidence in the bank. Some studies, such as 
Mostafa (2020), suggest that consumer confidence in the bank can intensify the positive effect of the attitude toward e-banking. If customers believe that their bank is honest and professional, their positive attitude toward the use of e-banking will result in a disposition to cocreate value with the bank by sharing information or providing feedback.

\section{DATA AVAILABILITY STATEMENT}

The raw data supporting the conclusions of this article will be made available by the authors, without undue reservation.

\section{REFERENCES}

Agarwal, R., and Karahanna, E. (2000). Time flies when you are having fun: cognitive absorption and beliefs about information technology usage. MIS Q. 24, 665-694. doi: $10.2307 / 3250951$

Ahmad, S., Bhatti, S. H., and Hwang, Y. (2019). E-service quality and actual use of e-banking: explanation through the technology acceptance model. Inf. Dev. 36, 503-519. doi: 10.1177/0266666919871611

Ajzen, I. (1991). The theory of planned behavior. Organ. Behav. Hum. Decis. Process. 50, 179-211. doi: 10.1016/0749-5978(91)90020-T

Akter, S., Motamarri, S., Hani, U., Shams, R., Fernando, M., Babu, M. M., et al. (2020). Building dynamic service analytics capabilities for the digital marketplace. J. Bus. Res. 118, 177-188. doi: 10.1016/j.jbusres.2020.06. 016

Andreu, L., Sainchez, I., and Mele, C. (2010). Value co-creation among retailers and consumers: new insights into the furniture market. J. Retail. Consum. Serv. 17, 241-250. doi: 10.1016/j.jretconser.2010.02.001

Baabdullah, A. M., Alalwan, A. A., Rana, N. P., Patil, P., and Dwivedi, Y. K. (2019). An integrated model for m-banking adoption in Saudi Arabia. Int. J. Bank Mark. 37, 452-478. doi: 10.1108/IJBM-07-2018-0183

Bankia (2020). Bankia Presenta el 'Humanismo Digital', Una Nueva Forma de Relacionarse Con Sus Clientes Basada en la Tecnología y las Personas. Available online at: 11Thttps://www.bankia.com/es/comunicacion/noticias/bankiahumanismo-digital-clientes-tecnologia.html11T (accessed October 7, 2020).

Bigné, E., Ruiz, C., Aldás, J., and Sanz, S. (2008). Influence of online shopping information dependency and innovativeness on internet shopping adoption. Online Inf. Rev. 32, 648-667. doi: 10.1108/14684520810914025

Carranza, R., Díaz, E., Martín-Consuegra, D., and Fernández-Ferrín, P. (2020). PLS-SEM in business promotion strategies. A multigroup analysis of mobile coupon users using MICOM. Ind. Manag. Data Syst. 120, 2349-2374. doi: 10.1108/IMDS-12-2019-0726

Chepurna, M., and Criado, J. R. (2018). Identification of barriers to co-create online: the perspectives of customers and companies. J. Res. Interact. Mark. 12, 452-471. doi: 10.1108/JRIM-01-2018-0018

Cohen, J. (1988). Statistical Power Analysis for the Behavioral Sciences, 2 Edn. Hillsdale, NJ: Erlbaum.

Davis, F. D., Bagozzi, R. P., and Warshaw, P. R. (1989). User acceptance of computer technology: a comparison of two theoretical models. Manage. Sci. 35, 982-1003. doi: $10.1287 / \mathrm{mnsc} .35 .8 .982$

Deb, M., and Lomo-David, E. (2014). An empirical examination of customers' adoption of m-banking in India. Mark. Intell. Plan. 32, 475-494. doi: 10.1108/ MIP-07-2013-0119

Dutot, V. (2015). Factors influencing near field communication (NFC) adoption: an extended TAM approach. J. High Technol. Manag. Res. 26, 45-57. doi: 10. 1016/j.hitech.2015.04.005

Fornell, C., and Larcker, D. F. (1981). Evaluating structural equation models with unobservable variables and measurement error. J. Mark. Res. 18, 39-50. doi: $10.1177 / 002224378101800104$

\section{AUTHOR CONTRIBUTIONS}

All authors listed have made a substantial, direct and intellectual contribution to the work, and approved it for publication.

\section{FUNDING}

This work was financed by group grants from the University of Castilla-La Mancha and co-financed by the European Union through the European Regional Development Fund (Project reference: 2020-GRIN-28990). Research Group: Research and Modelling in Marketing and Tourism (RMMT).

Glavee-Geo, R., Shaikh, A. A., and Karjaluoto, H. (2017). Mobile banking services adoption in Pakistan: are there gender differences? Int. J. Bank Mark. 35, 1090-1114. doi: 10.1108/IJBM-09-2015-0142

Grönroos, C. (2011). Value co-creation in service logic: a critical analysis. Mark. Theory 11, 279-301. doi: 10.1177/1470593111408177

Hair, J. F., Risher, J. J., Sarstedt, M., and Ringle, C. M. (2019). When to use and how to report the results of PLS-SEM. Eur. Bus. Rev. 31, 2-24. doi: 10.1108/EBR-112018-0203

Hair, J. F., Sarstedt, M., Ringle, C. M., and Gudergan, S. P. (2017). Advanced Issues in Partial Least Squares Structural Equation Modeling. Thousand Oaks, CA: SAGE Publications.

Henseler, J., Hubona, G., and Ray, P. A. (2016). Using PLS path modeling in new technology research: updated guidelines. Ind. Manag. Data Syst. 116, 2-20. doi: 10.1108/IMDS-09-2015-0382

Henseler, J., Ringle, C. M., and Sarstedt, M. (2015). A new criterion for assessing discriminant validity in variance-based structural equation modelling. J. Acad. Mark. Sci. 43, 115-135. doi: 10.1007/s11747-014-0403-8

Hosseini, M., Shajari, S., and Akbarabadi, M. (2020). Identifying multi-channel value co-creator groups in the banking industry. J. Retail. Consum. Serv. (in press). doi: 10.1016/j.jretconser.2020.102312

Ind, N., and Coates, N. (2013). The meaning of co-creation. Eur. Bus. Rev. 25, 86-95. doi: 10.1108/09555341311287754

Mainardes, E. W., Teixeira, A., and Romano, P.C.d.S (2017). Determinants of cocreation in banking services. Int. J. Bank Mark. 35, 187-204. doi: 10.1108/IJBM10-2015-0165

Malaquias, R. F., and Hwang, Y. (2019). Mobile banking use: a comparative study with Brazilian and U.S. participants. Int. J. Inf. Manag. 44, 132-140. doi: 10. 1016/j.ijinfomgt.2018.10.004

Malar, D. A., Arvidsson, V., and Holmstrom, J. (2019). Digital transformation in banking: exploring value co-creation in online banking services in India. J. Glob. Inf. Technol. Manag. 22, 7-24. doi: 10.1080/1097198X.2019.1567216

Martovoy, A., and Santos, J. (2012). Co-creation and co-profiting in financial services. Int. J. Entrep. Innov. Manag. 16, 114-135. doi: 10.1504/IJEIM.2012. 050446

Medberg, G., and Heinonen, K. (2014). Invisible value formation: a netnography in retail banking. Int. J. Bank Mark. 32, 590-607. doi: 10.1108/IJBM-03-20140041

Mostafa, R. B. (2020). Mobile banking service quality: a new avenue for customer value co-creation. Int. J. Bank Mark. 38, 1107-1132. doi: 10.1108/IJBM-112019-0421

Natarajan, T., Balasubramanian, S. A., and Kasilingam, D. L. (2018). The moderating role of device type and age of users on the intention to use mobile shopping applications. Technol. Soc. 53, 79-90. doi: 10.1016/j.techsoc.2018.01. 003

O'Hern, M., and Rindfleisch, A. (2010). Customer co-creation: a typology and research agenda. Rev. Mark. Res. 6, 84-106. doi: 10.1108/S1548643520090000006008

Oliveira, P., and von Hippel, E. (2011). Users as service innovators: the case of banking services. Res. Policy. 40, 806-818. doi: 10.1016/j.respol.2011.03.009 
Payne, A., Storkbacka, K., and Frow, P. (2008). Managing the co-creation of value. J. Acad. Mark. Sci. 36, 83-96. doi: 10.1007/s11747-007-0070-0

Ringle, C. M., and Sarstedt, M. (2016). Gain more insight from your PLS-SEM results: the importance-performance map analysis. Ind. Manage. Data Syst. 116, 1865-1886. doi: 10.1108/IMDS-10-2015-0449

Riquelme, H. E., and Rios, R. E. (2010). The moderating effect of gender in the adoption of mobile banking. Int. J. Bank Mark. 28, 328-341. doi: 10.1108/ 02652321011064872

Salimon, M. G., Bin Yusoff, R. Z., Sanuri, S., and Mokhtar, M. (2017). The mediating role of hedonic motivation on the relationship between adoption of e-banking and its determinants. Int. J. Bank Mark. 35, 558-582. doi: 10.1108/ IJBM-05-2016-0060

Schierz, P., Schilke, O., and Wirtz, B. (2010). Understanding customer acceptance of mobile payment services: an empirical analysis. J. Electron. Commer. Res. Appl. 9, 209-216. doi: 10.1016/j.elerap.2009.07.005

Schreieck, M., and Wiesche, M. (2017). "How established companies leverage it platforms for value co-creation - insights from banking," in Proceedings of the 25 the European Conference on Information Systems, Guimarães.

Shaikh, A. A., and Karjaluoto, H. (2015). Mobile banking adoption: a literature review. Telemat. Inform. 32, 129-142. doi: 10.1016/j.tele.2014.05.003

Shankar, A., and Jebarajakirthy, C. (2019). The influence of e-banking service quality on customer loyalty: a moderated mediation approach. Int. J. Bank Mark. 37, 1119-1142. doi: 10.1108/IJBM-03-2018-0063

Shankar, A., Jebarajakirthy, C., and Ashaduzzaman, M. (2020). How do electronic word of mouth practices contribute to mobile banking adoption? J. Retail. Consum. Serv. 52:101920. doi: 10.1016/j.jretconser.2019.101920

Sikdar, P., Kumar, A., and Makkad, M. (2015). Online banking adoption a factor validation and satisfaction causation study in the context of Indian banking customers. Int. J. Bank Mark. 33, 760-785. doi: 10.1108/ijbm-11-2014-0161

Singh, S., and Srivastava, R. K. (2020). Understanding the intention to use mobile banking by existing online banking customers: an empirical study. J. Financ. Serv. Mark. 25, 86-96. doi: 10.1057/s41264-020-00074-w

Statista (2020a). Tasa de Penetración de los Servicios de Banca Online en España. Available online at: https://es.statista.com/estadisticas/501217/tasa-depenetracion-de-los-servicios-de-banca-online-en-espana/ (accessed July 28, 2020).

Statista (2020b). Número de Clientes Digitales de los Principales Bancos con Presencia Digital en España. Available online at: https://es.statista.com/ estadisticas/506244/numero-de-clientes-digitales-de-los-principales-bancoscon-presencia-digital-en-espana/ (accessed July 29, 2020).

Stern, T., and Salb, D. (2015). Examining profile disclosure on online social networks: an affective, behavioural, and cognitive perspective. Int. J. Electron. Bus. 12, 162-184. doi: 10.1504/ijeb.2015.069106

Venkatesh, V., Morris, M. G., Davis, G. B., and Davis, F. D. (2003). User acceptance of information technology: toward a unified view. MIS Q. 27, 425-478. doi: $10.2307 / 30036540$

Wang, M., Cho, S., and Denton, T. (2017). The impact of personalisation and compatibility with past experience on e-banking usage. Int. J. Bank Mark. 35, 45-55. doi: 10.1108/IJBM-04-2015-0046

Yaseen, S. G., and El Qirem, I. A. (2018). Intention to use e-banking services in the Jordanian commercial banks. Int. J. Bank Mark. 36, 557-571. doi: 10.1108/ IJBM-05-2017-0082

Yoon, H. S., and Steege, L. M. B. (2013). Development of a quantitative model of the impact of customers' personality and perceptions on internet banking use. Comput. Hum. Behav. 29, 1133-1141. doi: 10.1016/j.chb.2012.10. 005

Zhang, T., Lu, C., and Kizildag, M. (2018). Banking "on-the-go": examining customers" adoption of mobile banking services. Int. J. Qual. Serv. Sci. 10, 279-295. doi: 10.1108/IJQSS-07-20170067

Zollo, L., Carranza, R., Faraoni, M., Díaz, E., and Martín-Consuegra, D. (2020). What influences consumers' intention to purchase organic personal care products? The role of social reassurance. J. Retail. Consum. Serv. (in press). doi: $10.1016 /$ j.jretconser.2020.102432

Conflict of Interest: The authors declare that the research was conducted in the absence of any commercial or financial relationships that could be construed as a potential conflict of interest.

Copyright ( 2021 Carranza, Díaz, Sánchez-Camacho and Martín-Consuegra. This is an open-access article distributed under the terms of the Creative Commons Attribution License (CC BY). The use, distribution or reproduction in other forums is permitted, provided the original author(s) and the copyright owner(s) are credited and that the original publication in this journal is cited, in accordance with accepted academic practice. No use, distribution or reproduction is permitted which does not comply with these terms. 